\title{
Hvem vokter vokterne - legeetikk i forsikringsmedisinen
}

\author{
De aller fleste norske leger holder seg innenfor de legeetiske kravene som er nedfelt i lover, forskrifter, \\ regler og retningslinjer som gjelder for utstedelse av legeerklæringer. I fire saker der leger ble innklaget \\ for henholdsvis Rådet for legeetikk og Helsetilsynet for uriktige opplysninger i legeerklæringer, er imidlertid \\ konklusjonene tvilsomme.
}

Kravet til etikk har til alle tider stått sentralt i legers virksomhet. Parallelt med utviklingen av velferdssamfunnet har legene fått stadig økende oppgaver som portvakt for samfunnets fellesgoder (1). Legeetikk er derfor blitt et spørsmål også om de sosiale og økonomiske konsekvensene av legenes arbeid (2).

For at fellesgodene skal forvaltes på en rettferdig måte med legenes hjelp, stilles det store krav til legenes ansvarsfølelse og etiske standard. Rådet for legeetikk i Den norske legeforening og Statens helsetilsyn skal vokte mot brudd på det etiske regelverket.

Men hvem vokter vokterne?

Gjensidige Forsikring er Norges største skadeforsikringsselskap. Hvert år sender selskapet ut flere tusen forespørsler til norske leger om helseopplysninger knyttet til tegning av forsikring og til krav om utbetaling. De fleste forespørslene er rettet til pasientens fastlege. I tillegg bestiller selskapet et betydelig antall spesialisterklæringer.

De aller fleste legeerklæringer som Gjensidige mottar, tilfredsstiller aktuelle lover, regler og andre avtaler (ramme 1) (3). De aller fleste erklæringene holder også tilfredsstillende kvalitet mht. omfang, detaljeringsgrad og relevans. Vi mottar imidlertid også en del legeerklæringer som etter vår mening ikke holder rimelige kvalitetsmål. Det kan dreie seg om alle grader av avvik, fra slurv, unøyaktigheter og mild fordreining av sannheten til mer bevisst tilbakeholdelse av relevante opplysninger, bruk av uriktige diagnoser og i sjeldne tilfeller direkte løgn.

I løpet av de siste årene har Gjensidige Forsikring sendt 14 saker til vurdering i Rådet for legeetikk og sju saker til Helsetilsynet. Selskapet har med det ønsket å få en «offisiell» vurdering av de krav som kan stilles til omfang, detaljeringsgrad og etterrettelighet i legeattester og legeerklæringer. I fire saker har vi ikke fått medhold $i$ vår vurdering av at legen har opptrådt i strid med Legeforeningens etiske regler eller helsepersonelloven. Etter vår vurdering er konklusjonene fra Rådet for legeetikk og Helsetilsynet i disse sakene diskutable.

I omtalen av disse sakene er det utelatt eller endret flere detaljer for at pasientene ikke skal kunne identifiseres.

\section{Sak 1}

En 38 år gammel kvinne søkte om uføreforsikring. Selskapet skrev til fastlegen bl.a. med spørsmål om legen kjente «helsemessige forhold for øvrig som kan ha betydning for bedømmelsen av forsikringssøknaden?». Legen svarte at pasientene hadde patologiske leverprøver, men at det ellers ikke var gjort patologiske funn. Søker fikk deretter uføreforsikring til normale vilkår.

Noen få år senere fremmet kunden krav om utbetaling avforsikringssummen pga. en sykdom som er sterkt assosiert med høyt alkoholforbruk. Selskapet innhentet derfor journalopplysninger fra den samme legen fra tiden før forsikringen ble tegnet. Der fremkom det opplysninger om betydelige alkoholproblemer, forhøyede leverfunksjonsprøver over lengre tid og pålegg om avholdenhet fra alkohol.

Selskapet mente at legen hadde tilbakeholdt relevante opplysninger om alkoholoverforbruk som ville ha fått konsekvenser for bedømmelsen, og ba Rådet for legeetikk vurdere legens svar opp mot etiske regler for leger, kap. IV, §4 (ramme 1). Rådet konkluderte med at disse forholdene ikke ga sikkert bilde av kontinuerlig alkoholmisbruk.

\section{Sak 2}

En 33 år gammel mann søkte om uføreforsikring og opplyste at tidligere legekontakt var begrenset til rutinekontroller. Vedkommende fikk uføreforsikring til normale vilkår. Få år senere fremsatte vedkommende krav om utbetaling av forsikringen pga. angst og depresjon. På spørsmål fra selskapet svarte legen at de aktuelle diagnosene var stilt flere år etter at forsikringen ble tegnet, og at legen var ukjent med tilsvarende sykdom/skade de siste ti år. Spørsmålet om relevante tilleggsopplysninger ble ikke besvart.

Selskapet mottok så kopi av erklæring fra samme lege til Nav, skrevet tre måneder tidligere, der det tydelig fremgikk at forsikringstaker hadde hatt betydelige psykiske vansker og hadde vært intravenøs rusmiddelmisbruker frem til noen år før forsikringen ble tegnet.

Selskapet mente at legen i sin erklæring hadde unnlatt å gi viktige bakgrunnsopplysninger som ville belyst relevante årsaksfak-
RAMME 1

Utdrag fra aktuelle lover og regler som gjelder for legers utstedelse av attester og andre legeerklæringer

- Lov om helsepersonell §15. Krav til attester, legeerklæringer o.l. Den som utsteder attest, erklæring o.l. skal være varsom, nøyaktig og objektiv. Attest, erklæring o.l. skal være korrekt og bare inneholde opplysninger som er nødvendige for formålet. Attest, erklæring o.l. skal inneholde alle opplysninger som helsepersonellet bør forstå er av betydning for mottageren og for formålet med attesten, erklæringen o.l. Helsepersonellet skal gjøre det klart dersom attesten, erklæringen o.l. bare bygger på en begrenset del av de relevante opplysningene helsepersonellet har.

$\S 3$. En lege skal bygge sine erklæringer på nødvendig innhentet informasjon og på så omfattende undersøkelser som formålet tilsier.

\section{- Etiske regler for leger}

Kap IV. Regler for legers utstedelse av attester og andre legeerklæringer $\S 4$. En legeerklæring skal gi tilstrekkelig informasjon til å fylle sin hensikt og skal være objektiv og nøytral i sin form. Relevante opplysninger må ikke forties eller fordreies. Erklæringen skal ikke inneholde informasjon som går utover formålet. Når medisinske dokumenter laget for andre formål brukes som vedlegg, skal det i særlig grad tas hensyn til taushetsplikten.

torer for å kunne ta stilling til graden og varigheten av arbeidsuførheten. Både ved å svare uriktig og ved helt å unnlate å svare på selskapets spørsmål kunne legen ha forledet selskapet til å treffe avgjørelser på uriktig medisinsk grunnlag.

Rådet for legeetikk ble bedt om å vurdere hvorvidt legen hadde tilbakeholdt relevante opplysninger i strid med etiske regler for 
leger, kap. IV, §4 (ramme 1). Rådet mente at opplysningene fra den innklagede legen var tilstrekkelige for den vurderingen forsikringsselskapet må gjøre og ga derfor ikke selskapet medhold i klagen.

Vårt selskap avslo utbetalingen og sa opp forsikringen.

\section{Sak 3}

En 25 år gammel mann fremmet krav overfor Gjensidige knyttet til diagnosen postinfeksiøst utmattelsessyndrom etter en infeksjon. Pasienten var henvist til spesialist i nevrologi, som skrev at vedkommende hadde hatt god helse, bortsett fra ryggplager, før den antatt utløsende infeksjonen.

Selskapet mottok så opplysninger fra fastlegen, der det fremkom at legen hadde journalført en lang rekke helseplager, mange av antatt psykosomatisk natur, og stilt 15 ulike diagnoser i tillegg til ryggplagene før diagnosen postinfeksiøst utmattelsessyndrom ble stilt.

Sykehistorien er en viktig kilde som skal inngå både ved inklusjon og eventuell eksklusjon av diagnosen kronisk/postinfeksiøst utmattelsessyndrom. For at selskapet skal kunne vurdere årsaken til og varigheten av arbeidsuførheten, er det viktig at diagnosen er korrekt og stilt på grunnlag av riktige kriterier. Etter vår vurdering hadde spesialisten ikke tatt hensyn til pasientens tidligere sykehistorie på en adekvat måte.

Rådet for legeetikk ble bedt om å vurdere om spesialisten hadde handlet i overensstemmelse med etiske regler, kap. IV, $\S 3$ (ramme 1). Rådet mente at spørsmålet hvorvidt anamnesen og utredningen var fyllestgjørende eller ikke, er et medisinskfaglig spørsmål som rådet ikke behandler, jf. reglement for Rådet for legeetikk, §2, 2. ledd. Rådet ga derfor ikke klager medhold.

\section{Sak 4}

I forbindelse med et krav om erstatning ved barneforsikring ønsket Gjensidige (i ettertid) å få avklart om den tilstanden som det ble søkt erstatning for, hadde vært til stede allerede før forsikringen ble tegnet. Fastlegen skrev til selskapet at moren hadde oppsøkt legen med barnet samtidig som forsikringen ble tegnet, med symptomer som tydet på en alvorlig nevrologisk sykdom. I en erklæring til selskapet en måned senere oppga fastlegen det samme tidspunktet for første legebesøk og opplyste at pasienten var blitt henvist til spesialisthelsetjenesten.

Selskapet mottok imidlertid en ny erklæring fra fastlegen flere måneder senere, der han nå skrev at det var «uklarheter» om tidspunkt for symptomdebut og diagnosesetting og presiserte at henvisningen til spesialisthelsetjenesten «primært» gjaldt utredning for mageproblematikk.

Selskapet mente det var en betydelig uoverensstemmelse mellom det som fastlegen skrev i sitt første brev og erklæringen til selskapet, der han klart uttrykte mistanke om alvorlig, kronisk nevrologisk sykdom, sammenholdt med det han skrev i sin siste erklæring.

Selskapet ba Statens helsetilsyn vurdere hvorvidt fastlegens siste erklæring var i overensstemmelse med helsepersonelloven kap. 2, krav til helsepersonells yrkesutøvelse, særlig $\S 15$, om krav til attester, erklæringer o.l. (ramme 1). Statens helsetilsyn kom til at alle de tre erklæringene som var utstedt i forbindelse med forsikringssaken var korrekte og at det ikke forelå brudd på helsepersonelloven $\S 15$.

Vårt selskap avslo utbetalingen og sa opp forsikringen.

\section{Diskusjon}

For å kunne foreta en mest mulig korrekt risikovurdering ved søknad om personforsikringer og et mest mulig riktig forsikringsoppgjør, er forsikringsselskapene i stor grad avhengige av opplysninger fra legene. Disse opplysningene må gi et mest mulig korrekt bilde av vedkommendes medisinske tilstand i henhold til de spørsmålene selskapene stiller, jf. også etiske regler for leger og helsepersonelloven.

Legens rolle som kyndig til å utstede attester krever en nøytralitet og en objektivitet som vil kunne sette rollen som behandlende lege på prøve. Det kan by på store utfordringer for en lege å avgi uttalelse til forsikringsselskap, som i siste instans kan vise seg å bli økonomisk ufordelaktig for pasienten (4). Det finnes gode anvisninger om hvordan leger skal utstede attester, erklæringer o.1. (5-8).

Våre erfaringer er at de aller fleste norske leger holder seg godt innenfor de legeetiske kravene som er nedfelt i lover, forskrifter, regler og retningslinjer. Vi mener imidlertid at Rådet for legeetikk i de tre omtalte sakene har gitt de aktuelle legene svært romslig beskyttelse. Vi må ta rådets konklusjoner til orientering, ettersom dets avgjørelse er bindende for medlemmene av foreningen og vedtak i enkeltsaker ikke kan overprøves.

I sak 4, som ble oversendt Statens helsetilsyn, mente vi at fastlegen $i$ ettertid hadde endret sine uttalelser. Helsetilsynet avviste våre argumenter, endog etter fornyet gjenomgang av saken. Denne konklusjonen må vi også ta til orientering, da Helsetilsynets avgjørelse er endelig.

Som et stort forsikringsselskap med et betydelig samfunnsansvar og med behov for samhandling med nøkterne og objektive leger, ser vi med bekymring på at Rådet for legeetikk og Helsetilsynet mener at legenes fremgangsmåte i disse sakene var etisk akseptabel. Leger kan gjøre sine pasienter en bjørnetjeneste ved å gi feilaktige medisinske opplysninger. En forsikringsavtale inngått på grunnlag av uriktige medisinske opplysninger kan i ettertid vise seg å være ugyldig. Det er et paradoks at kunden blir tatt for svik og mister forsikringen, mens legen i slike saker kan gå fri.
Vi mener at Rådet for legeetikk og Helsetilsynet i disse sakene har kommet frem til avgjørelser som er høyst diskutable. Vi tilstreber en mest mulig riktig og objektiv vurdering av korrekte og relevante medisinske opplysninger. Dette mener vi «vokterne» burde være enige med oss $i$.

Det kan bli et problem dersom tvilsomme legeuttalelser blir «beskyttet», slik disse eksemplene etter vår mening illustrerer. Dersom disse konklusjonene fra våre «voktere» - Rådet for legeetikk og Helsetilsynet - blir retningsgivende, vil dette etter vår mening gi et urimelig stort handlingsrom for tilpasning av vurderinger og erklæringer fra legene.

\section{Jan Harald Dobloug \\ jan.dobloug@gjensidige.no \\ Gjensidige Forsikring}

Jan Harald Dobloug (f. 1950) er spesialist $i$ indremedisin og infeksjonssykdommer, dr.med., master i helseadministrasjon og medisinsk direktør i Gjensidige Forsikring. Forfatter har fylt ut ICMJE-skjemaet og oppgir utover sin stilling som medisinsk direktør i Gjensidige ingen interessekonflikter.

Litteratur

1. Gulbrandsen P. Førde R, Aasland OG. Hvordan ha legen det som portvakt? Tidsskr Nor Lægeforen 2002; 122: 1874-9.

2. Winther $F \varnothing$. Førde R. Etikk. Store norske leksikon. http://snl.no/.sml_artikkel/etikk (15.10.2012).

3. Den norske legeforening. Normaltariffen.'Honoraravtalen' mellom Finansnæringens Fellesorganisasjon (FNO) og Den norske legeforening. http://legeforeningen.no/Arbeidsliv-og-jus/ naringsdrivende/Normaltariffen/ (15.10.2012)

4. Hanstad AM. Legene og attestene. Om attester. etikk og legerollen. Utposten 2007; nr. 3: 22-4.

5. Forskrift om krav til helsepersonells attester. erklæringer o.l. www.lovdata.no/cgi-wift/ Idles?doc=/sf/sf/sf-20081218-1486.html (15.10.2012).

6. Sosial- og helsedirektoratet. Krav i forbindelse med utstedelse av attester/helseerklæringer o.l. Rundskriv IS-9/2006. www.une.no/upload/ PDF\%20dokumenter/Kap7_rundskriv_SHDIR.pdf (15.10.2012).

7. Fortelling - funn - fortolkning - formidling. En praktisk veileder for legers attestarbeid i spennet mellom innsikt, innlevelse, rammer og ressurser Oslo: Den norske legeforening, 2008. http://legeforeningen.no/PageFiles/30457/ En\%20praktisk\%20veileder\%20for\%20legers\%20 attestarbeid\%20(pdf).pdf (15.10.2012).

8. Ot.prp. nr. 25 (2007-2008). Om lov om endringer i helsepersonelloven og helseregisterloven.

Mottatt 18.5. 2012, første revisjon innsendt 9.8. 2012, godkjent 3.1. 2013. Medisinsk redaktør Petter Gjersvik 